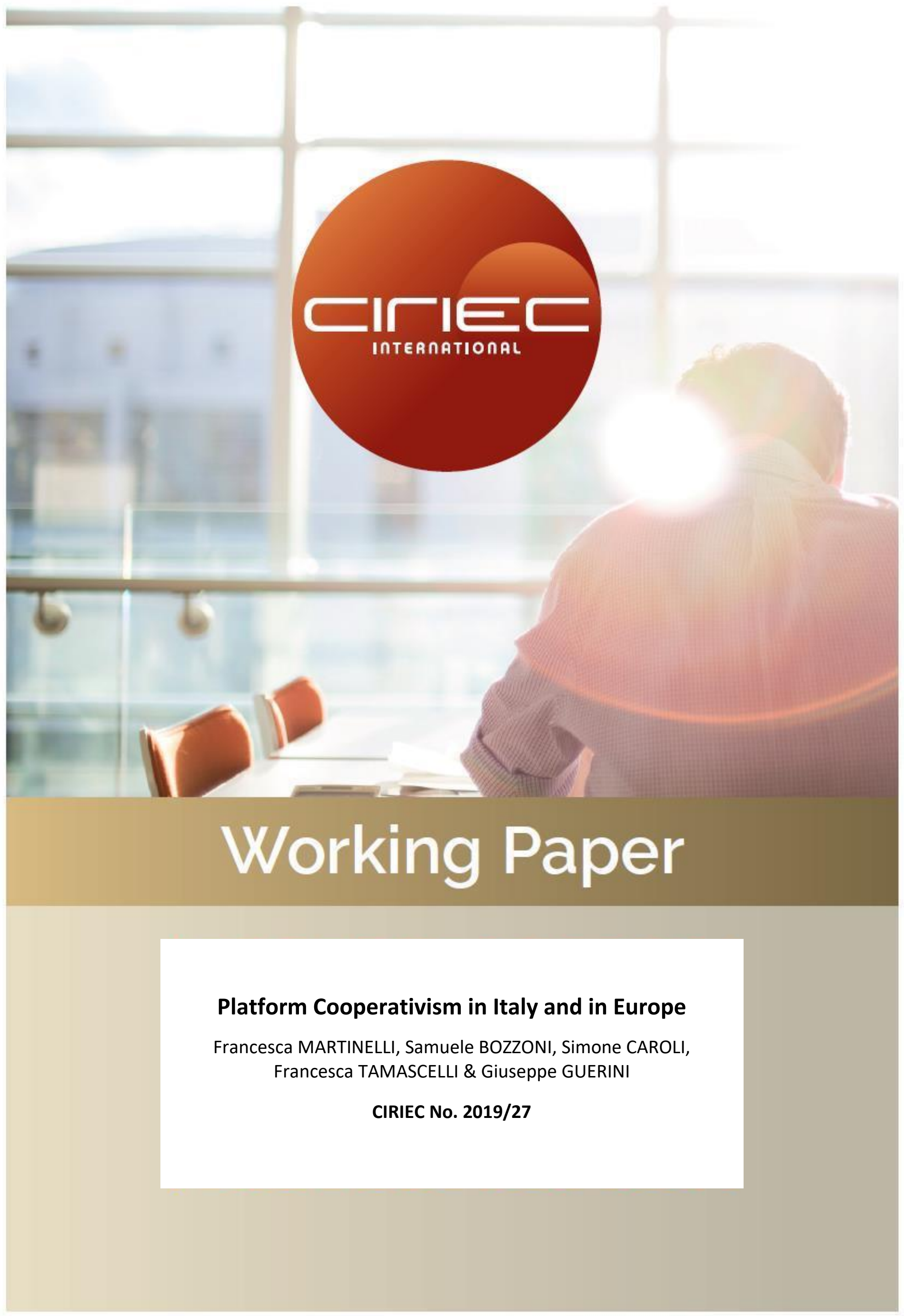


CIRIEC activities, publications and researches are realised with the support of

Les activités, publications et recherches du CIRIEC sont réalisées avec le soutien de
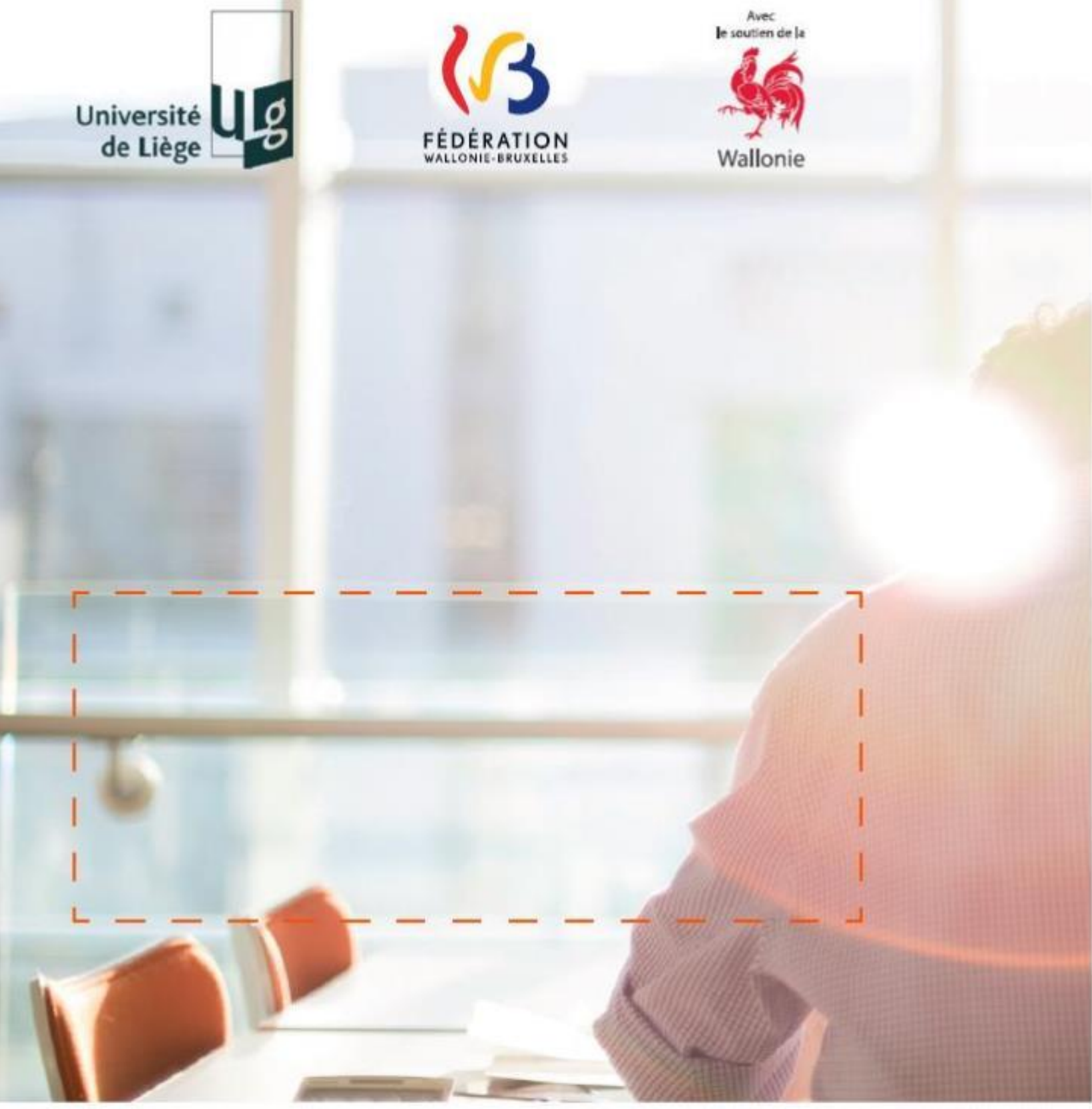


\title{
Platform Cooperativism in Italy and in Europe ${ }^{1^{*}}$
}

\author{
Francesca Martinelli ${ }^{2}$, Samuele Bozzoni ${ }^{3}$, Simone Caroli ${ }^{4}$, \\ Francesca Tamascelli ${ }^{5}$ and Giuseppe Guerini ${ }^{6}$
}

Working paper CIRIEC No. 2019/27

1* Paper presented at the $7^{\text {th }}$ CIRIEC International Research Conference on Social Economy "Social and Solidarity Economy: Moving Towards a New Economic System", Bucharest (Romania), 6-9 June 2019.

2 Fondazione Centro Studi Doc, Verona (Italy) (Email: info@centrostudidoc.org).

${ }^{3}$ Confcooperative Lombardia (Italy) (Email: samuelebozzoni@gmail.com).

${ }^{4}$ Confcooperative Modena (Italy) (Email: carolisimone@gmail.com).

${ }^{5}$ Legacoop Estense - Culture and Media (Italy) (Email: f.tamascelli@legacoopestense.coop).

${ }^{6}$ Cecop - Cicopa Europe (Email: guerini.g@confcooperative.it). 


\begin{abstract}
This research investigates some cases of cooperative platforms in the field of workerowned cooperation and consumer cooperation and explores the effects of the merger of platform technology with cooperation. The research focuses on the main consequences of this merger on the organizational model and the engagement level of individuals and studies the change of attitudes of providers and consumers when they are engaged in a cooperative project. The argument is that a cooperative platform can offer solutions and answers to both platform workers' needs and problems of modern consumption by allowing both providers and consumers to join the entrepreneurial project, share resources - and, in specific cases, earnings - in an equal way, and be part of a community. Against the outsourcing and dispersive models of a classical digital platform, such as Deliveroo, Uber or Airbnb, where providers and consumers are separated and isolated, a cooperative platform enables the propensity of providers and consumers to engage in collective actions and become the protagonist of the platform activity. In this way, the organizational form of a cooperative platform is both an alternative to classical digital platforms and an evolution of traditional cooperative models.
\end{abstract}

Keywords: Platform cooperativism, Gig workers, Prosumers, Digital platform, Platform work

JEL Code: 035 


\section{Introduction}

An online digital platform is an application that offers matching of a consumer with services' or goods' providers. The application acts as a digital intermediary for organizing and managing providers' activity (drivers, riders, hosts, etc.) according to consumer needs. Today digital platforms offer digitally-delivered services and/or facilitate physically delivered services (Vandaele, Piasna, and Drahokoupil, 2019), and generate "remote gig work" or "local gig work" (Wood et al., 2018). Most of the applications are based on an in-house algorithm that provides automated task allocation, shifting a range of managerial responsibilities from humans to machines (Aloisi, 2016). For this reason, most of the digital platforms are lean platforms (Snricek, 2017) defining themselves only as a "matching system" between providers and consumers, even if both are affected by the ever-increasing presence of digital platforms.

Claiming no responsibility on workers as providers, digital platforms radicalize the practice of outsourcing: they outsource even the activity and goods of their core business (e.g. the driver in Uber, the riders in Deliveroo, the host and the house in Airbnb, etc.) (Smorto, and Bonini, 2017); and providers which usually supply their capital equipment, are compensated on a piece-work basis - not on an hourly basis -, they are engaged as independent contractors, and considered as freelancers (Kalamar, 2013; Scholz, 2014; Schor, 2014; Cherry, and Aloisi, 2017; Srniceck, 2017; Sundararajan, 2017; Vandaele, 2018). Providers complain about non- and low payment, income insecurity, the lack of compensation for their capital equipment, health, and safety risks, blurring boundaries between work and private life, and lack of transparency regarding surveillance practices, rating systems, and the task or job allocation (Vandaele, 2018). Situations leading to possibilities of exploitation are due to the legal vagueness of the relationship between the digital platform, as an intermediary, and the providers. And when providers end up in the so-called "grey zone" of work (Castelvetri, 2010) the companies' owners of digital platforms are exonerated from taking responsibility as employers (Drahokoupil, and Fabo, 2016).

At the same time, consumers are affected by digital platforms that not always respect consumers' law and rights. The main difficulties for consumers concern products, transparency, and competition. First of all, the quality of products

\footnotetext{
${ }^{7}$ The grey zone identifies the types of work that have an indeterminate physiognomy, oscillating between dependent and independent work: even if the worker has a subordinated relation to an employer, he is an independent contractor with no access to the social protection of an employee.
} 
offered by platforms is substandard, when not even unsafe (Baker, 2014; European Commission, 2017). Moreover, digital platforms are not enough transparent about their practices and terms and conditions (business models, use of data, etc.), so consumers are unable to make informed choices. Usually, the lack of/-or ambiguous information is related to the use of private data, the liability of platforms (e.g. in case of fraud), payment methods, pricing techniques (referring to personalised or dynamic pricing and ranking mechanisms), change of conditions and guarantees, etc. (BEUC, 2018). The lack of transparency impacts innovation and competition too. On one side, dominant platforms' rating systems are neither fully reliable nor transparent (European Commission, 2017). On the other side, dominant platforms seem to lock users in unfair and constantly changing terms and conditions hampering competition and innovation (BEUC, 2018; Zuboff, 2019).

Considering both workers as providers and consumers, we observe a general lack of bargaining power among them and digital platforms. Thus, the role of digital platforms may go well beyond the provision of automated task allocation through an opaque algorithm, or a "matching system", and have positive effects on community and territories. It can stimulate not only a different engagement level and use of workers as providers and consumers but also introduce new forms of interactions in the classical cooperation model with positive effects on governance and participation.

\section{Digital platforms and cooperation}

The debate about alternative ways to manage digital platforms and guarantee the protection and engagement of both workers and consumers is currently led by "platform cooperativism". The term was coined by the scholar-activist Trebor Scholz and first introduced in a 2014 article on Medium (Scholz, 2014), followed in 2017 by his book Uberworked and Underpaid (Scholz, 2017). Then, Trebor Scholz and the journalist Nathan Schneider popularized the concept with "Platform Cooperativism. The Internet. Ownership. Democracy", the first platform cooperativism conference held in 2015 at The New School of New York, and with their jointly edited book Ours to Hack and to Own published in 2017 (Scholz, and Schneider, 2017).

Platform cooperativism was launched with a simple announcement: cloning the technological heart of Uber, Task Rabbit, Airbnb, or UpWork, reshaping these technologies putting them to work with different ownership models, such as unions, cities, and, above all, cooperatives, and reframing concepts like innovation and efficiency to benefit everybody. Trebor Scholz presented the 
cooperation as an alternative already in the first article he published on Medium in 2014: "Let us apply the power of our technological imagination to practice forms of cooperation and collaboration. Worker-owned cooperatives could design their own apps-based platforms, fostering truly peer-to-peer ways of providing services and things, and speak truth to the new platform capitalists. [...] Worker-owned cooperatives can offer an alternative model of social organization to address financial instability" (Scholz, 2014). The choice of cooperatives is then explained even by Nathan Schneider in an article he published some weeks later on Shareable!: "Co-ops help ensure that the people who contribute to and depend on an enterprise keep control and keep profits, so they're a possible remedy for worsening economic inequality" (Schneider, 2014; Smorto, and Bonini, 2017).

A cooperative is an autonomous association of persons united voluntarily to meet their common economic, social, and cultural needs and aspirations through a jointly-owned and democratically-controlled enterprise (International Cooperative Alliance, 1995). Integrating this definition with digital platforms, a platform cooperative, or platform co-op, is an enterprise cooperatively owned and democratically governed by those who depend on it (workers, users, and other relevant stakeholders) that builds a digital platform (website, mobile app or protocol) to facilitate the trade of goods and services. Applying the cooperation definition and its principles to digital platforms, the technology from an ambiguous matching system becomes a tool in the service of workers/providers and consumers.

Following this idea, a new generation of internet entrepreneurship is growing all over the world contrasting large-scale for-profit corporations that are exploiting online collaboration among peers (Internet Health Report, 2019). At the same time, already existing cooperatives in many countries in the world are recognizing themselves in the theoretical framework of the movement. This is leading both to experimentations around shared ownership and shared governance in the digital economy, and the introduction of platform technology in long-history cooperatives.

The following sections will focus on both new experimentations and existing cooperatives that across Europe are dealing with platform cooperativism. In particular, we will concentrate on some examples of worker-owned cooperatives and consumption and multi-stakeholder cooperatives. 


\section{Worker-owned cooperatives}

The relation among digital platforms and workers as providers is today constantly questioned by digital platforms' owners, claiming to be only intermediary with no responsibility on those who offer their services to the platform. And while providers end up being in the so-called "grey zone" of work (Castelvetri, 2010), Western Countries are facing some difficulties in shaping these new forms of work into their employment law, usually based on the classic employed work.

In this frame, new cooperative models have appeared to offer decent work conditions and access to social protection schemes. Particularly, in Europe, we find some innovative models of worker-owned cooperatives using digital platforms to support members' activities. The reference goes to the model of self-management platform cooperative developed by the Italian cooperative Doc Servizi (Martinelli, 2017), the French model of Business and employment cooperatives (BEC) with the example of the Parisian Coopaname (Bost, 2011; Bureau, and Corsani, 2015; Boudes, 2019), and the Smart ecosystem created by Smart Belgium (Cecop, 2019).

We will examine these cases in more detail in the next pages underlining how each of these cooperative models has different characteristics and approaches regarding the reason of their creation, their organisation (how they employ their members), the role of the platform, and their social and political activity.

\section{Italy: Doc Servizi and its network}

Founded in 1990 in Verona, Doc Servizi (https://iprofessionistidellospettacolo .docservizi.it/) is a self-management platform cooperative, which is an evolution of a classic worker cooperative. Doc Servizi was created by workers to obtain decent work at the best economic and moral conditions and, in particular, with the purpose to valorise collectively the work of professionals in the field of music, art, and theater through cooperation. To date, Doc Servizi has about 6,000 members, 34 branches all over Italy, 1 branch in Paris and closed 2019 with about 58 million euros of turnover. It has created a bigger network (www.docservizi.it) composed of eight societies that together cover all sectors of the cultural and creative industries, count more than 8,000 members and closed 2019 with 71 million euros of turnover. 
Since its birth, Doc Servizi's members are hired as subordinate workers (art. 2094 of the Civil Code) ${ }^{8}$ safeguarding at the same time the autonomous management of their activities: they are thus able to maintain the intellectual independence typical of self-employment with the social protection due to employees. For members operating in the show business, that do not have a working continuity, the employment contract applied is the Italian "job on-call contract" (artt. 13-18 of D.Igs. 81/2015 "Jobs Act"). This contract remains active even when the work activity is suspended and it guarantees the continuity of relationship and social security. Using this contract to become employees of the cooperative, show business workers have the opportunity both to safeguard their autonomy in the management of their activity and obtain the social protection of employees (Martinelli, 2017).

Over the years, members have developed new activities centrally organized by the cooperative to offer new services to customers, such as administrative, accounting and contracts management, event and entrepreneurial projects consultancy, initial and specialized training, a travel agency, an e-commerce platform to sell members' products, work and public safety procedures, legal and family advice, etc. Moreover, Doc Servizi's members organized themselves with specific offices, such as a marketing \& communication office, a call for tender offices, a safety and training office, 34 offices in Italy, specific peer communities, and various business units.

To manage all these activities Doc Servizi can count on a very efficient and highly technological in-house digital platform, which optimizes many procedures translating expertise in digital processes. Doc Servizi's platform is based on a scalable and replicable technology, which makes it adaptable to different projects of the network. The platform is also used to sell members' products, to connect them with clients with a showcase website, to manage safety procedures, to collect and share royalties, to build working groups, etc. The digital platform has increasingly become a structural tool of the cooperative that guarantees each working member the autonomous management of his activity while remaining within the boundaries of the protected work.

The attention to safeguard and support the autonomy and peculiar expertise of each member is what makes Doc Servizi a self-management platform cooperative, which is a typology of cooperatives that was born in Italy in the

\footnotetext{
${ }^{8}$ Art. 2094 Civil Code: a subordinate worker is a person who undertakes, through remuneration, to collaborate in the company, lending his intellectual or manual work under the direction of the entrepreneur.
} 
Seventies within the MAG experience in Verona (Mutual Society for SelfManagement: https://magverona.it). In self-management cooperatives working members have two "roles": as workers they collaborate in the company and respect their general directives, rules, and objectives, and as members they manage manual or intellectual activities in autonomy according to their skills and abilities, that are unique and irreplaceable - characteristics that make them experts and autonomous in the sector in which they operate.

Regrouping workers usually fragmented on the market, Doc Servizi has begun to perform as spokespeople for their members. This activity lead Doc Servizi, with the support of the Centro Studi Doc Foundation (www.centrostudidoc.org), to participate in the public debate around rights and labour law regarding not only its members but all workers active in culture and creative industries. Two examples where the expertise of Centro Studi Doc Foundation was involved are a decree dedicated to the safety of technicians ("Decreto Palchi e Fiere") delivered in 2014 and the first Italian collective bargaining agreement (CBA) for the professionals of the arts who work in a cooperative signed in 2014 (Chiappa 2014, 2018; Chiappa, and Martinelli, 2019).

\section{France: the BEC model and the example of Coopaname}

Coopaname (www.coopaname.coop) is a Parisian Coopérative d'Activités et d'Emploi (CAE), a Business and employment cooperative (BEC) (Bost, 2011; Bureau, and Corsani, 2015; Boudes, 2019). Created in $2004^{9}$ Coopaname is today a worker cooperative $\left(\mathrm{Scop}^{10}\right)$ with six offices in Île-de-France. Coopaname has about 850 workers and closed 2019 with about 10 million euros of turnover. For this reason, it is the largest BEC in France and it collects a great variety of professions and skills.

The BEC was created to answer the social need of isolated self-entrepreneurs and offer them a valid alternative to the individual creation of an enterprise allowing testing a project within the framework of a shared company, the cooperative. A BEC is then an entrepreneurial platform supporting entrepreneurs in many ways: legal, administrative and accounting management, entrepreneurial education (e.g. in communication, marketing, sales, etc.), experiences sharing with other entrepreneurs and participation in

\footnotetext{
${ }^{9}$ The first BEC was created in 1995.

${ }^{10}$ Coopaname is in fact a Scop-SA: Scop is acronym for Société coopérative et participative, and former acronym of Société Coopérative Ouvrière de Production. A Scop is a worker cooperative. SA is an acronym for société anonyme, public limited company.
} 
the corporate governance (Ballon, and Bodet et al., 2018). At an operating level, the new entrepreneur who enters a BEC benefits from a legal framework and social protection through the acquisition of the status of "employee entrepreneur" (LOI n 2014-856 du 31 juillet 2014 relative à l'économie sociale et solidaire or Loi Hamon) signing a CESA (Contrat d'entrepreneur salarié associé, Contract of employee entrepreneur member), a contract with essentially the same characteristics as a permanent contract. The entrepreneur keeps his autonomy in the management of his business (brand name, customer management, fare's definition, etc.), but at the same time becomes an employee of the cooperative, where he can even practice "multi-activity", which means that he can put in place different and various economic activities (Martinelli, 2018).

In this context, Coopaname was founded in Paris to answer to the lack of BECs in the French capital, which limited the dialogue with institutions. Coopaname has therefore been created in 2004 to become the "showcase" (Veyer, 2007, 2011) of the whole movement, and represent its political needs. For this reason, Coopaname participated actively at the most important turning point for $B E C s$, which was the recognition of its social role with the insertion of a section dedicated to them in the Law of July 312014 concerning the Social and Solidarity Economy then applied with the decree of 27th October 2015 relating to Business and employment cooperatives and employee entrepreneurs.

Today, Coopaname's goal is to become an alternative model to individual entrepreneurship and traditional employee labour through the strength of its community, which is the engine for its action. In this way, it supports not only the activity of its members but of all the freelancers. Coopaname pursues this objective by the multiplication of opportunities to participate in its governance, to exchange knowledge and practices through training and peer communities, to work together thanks to co-working spaces and an extranet (Martinelli, 2017).

The extranet, called "Le Stranette", is the heart of Coopaname's platform because it is the internal social network of the cooperative (where entrepreneurs can discuss with each other and create their own groups), the portal to online applications used by entrepreneurs to manage their entrepreneurial activities (accounting, contracts, reimbursement of expenses, etc.), and sign up for training courses. In Coopaname the in-house digital platform is used not only to optimize procedures but above all to create connections among entrepreneurs and external clients (e.g. through a public yearbook connected with the extranet). 
In Coopaname, workers are looking for an opportunity to avoid precariousness and build a different way of working together ("travailler autrement"). For this reason, they consider themselves neither employees nor self-employed, but as cooperators they conceive the working relationship as based on a social bond, rather than on a relationship of subordination or of a commercial nature (Nony, and De Grenier, 2019; Cecop, 2019). In this context, is born the ambition to activate a real "mutualistic dynamic" and to transform the cooperative into a "mutual society of work" ("mutuelle de travail") (Martinelli, 2018).

\section{Belgium: Smart and its European network}

Smart is a mutual risk cooperative (Scholz, 2019) and was founded in Belgium (https://smartbe.be/fr/) in 1998 to support artists in the development of their activities through mutualized services and a digital platform that makes it easier to invoice their multiple and discontinued activities. In the beginning, Smart, was a non-profit association and became a multi-stakeholder cooperative in 2016. Today, Smart is a network of cooperatives and companies active in eight other countries in Europe, including Italy and France. The entire Smart network today brings together 35,000 workers across Europe (of which 22,000 in Belgium and France) has offices in 37 cities (of which 24 in Belgium and France), and closed 2018 with a turnover of 200 million euros (of which 190 in Belgium and France).

Smart works with freelancers, organisations, and entrepreneurs by mutualizing various services, in particular administrative, financial and accountancy management services, insurance services, legal and consulting services, information and training, co-work spaces and mutual financial tools. Focus at first on artistic and creative workers, then Smart opened up to all freelancers and recently to platform workers too. In the cooperative, the workers become all together shareholders, economic developers, and salaried workers thanks to either fixed-term or open-ended employment contracts (Cecop, 2019).

Concerning the digital platform, Smart's main activity consists in transforming invoices into salaries and expenses. Smart's most important service is to provide freelancers with an employment contract as an employee of Smart. The mechanism is explained in the recent Cecop report All for one. Response of worker-owned cooperatives to non standard employment: "When freelancers find their own clients with whom they negotiate terms and conditions of product or service to be delivered, they fill out an order form online. Once it is signed by the client, Smart sends an invoice to the client. A contractual arrangement (and expenses) is set between the freelancer and Smart. Smart then becomes the freelancers' employer for the duration of the contract, 
allowing freelancer to be salaried and opening up rights to social security. Smart manages all administrative processes as an employer" (Cecop, 2019, p. 26). In this way, Smart offers freelancers the social protection of employees without taking away their autonomy in business management.

In 2015, Smart Belgium found that some of its members were working as platform workers for food delivery online platforms ${ }^{11}$ to increase their incomes. Thanks to the huge number of its members involved in platform work and considering that food delivery platforms were using Smart as intermediary (Drahokoupil, and Piasna, 2019), between 2016 and 2018 Smart obtained an agreement with the main platforms to protect their members' working conditions (minimum wages, on-time payment, minimum working hours, income guaranteed, covering some working costs, safety and security training). Even if the arrangement was motivated by the characteristics of the Belgian tax system and, for this reason, after the introduction by the Belgian government of some institutional measures in support of online platforms, the agreement was unilaterally ended by the food delivery platform, it was nevertheless an experiment to guarantee social protection to platform workers (Drahokoupil, and Piasna, 2019; Cecop, 2019). Smart aimed to provide better working conditions to workers it believed should have been hired directly by the food delivery platforms, but since that did not happen, Smart decided to take action and provides a solution.

\begin{tabular}{|c|c|c|c|}
\hline & Doc Servizi & Coopaname & Smart Belgium \\
\hline Date of birth & $\begin{array}{l}1990 \\
\text { Verona (Italy) }\end{array}$ & $\begin{array}{l}2004 \text { (BEC 1995) } \\
\text { Paris (France) }\end{array}$ & $\begin{array}{l}1998 \\
\text { Brussels (Belgium) }\end{array}$ \\
\hline Created by & $\begin{array}{l}\text { Musicians to obtain } \\
\text { decent work at the best } \\
\text { economic and moral } \\
\text { conditions using the self- } \\
\text { management } \\
\text { cooperation model. }\end{array}$ & $\begin{array}{l}\text { The BEC network to be the } \\
\text { «showcase» of the whole } \\
\text { movement, and represent } \\
\text { its political needs. }\end{array}$ & $\begin{array}{l}\text { A non-profit association that } \\
\text { supports artists in the } \\
\text { development of their } \\
\text { activities through } \\
\text { mutualized services and a } \\
\text { digital platform that makes } \\
\text { it easier to invoice their } \\
\text { multiple and discontinued } \\
\text { activities. }\end{array}$ \\
\hline $\begin{array}{l}\text { Typology of worker- } \\
\text { owned cooperative }\end{array}$ & $\begin{array}{l}\text { Worker coop and self- } \\
\text { management platform } \\
\text { cooperative. }\end{array}$ & $\begin{array}{l}\text { Scop (worker coop) and } \\
\text { Business and employment } \\
\text { cooperative (BEC). }\end{array}$ & $\begin{array}{l}\text { Multi-stakeholder } \\
\text { cooperative. }\end{array}$ \\
\hline Members & $\begin{array}{l}6.000 \text { cultural and } \\
\text { creative industry } \\
\text { professionals. }\end{array}$ & $\begin{array}{l}850 \text { entrepreneurs (of } \\
\text { which about } 300 \text { are } \\
\text { members too). }\end{array}$ & $\begin{array}{l}22.000 \text { freelancers (in } \\
\text { Belgium and France). }\end{array}$ \\
\hline Turnover 2018 & 50,5 millions. & 10 millions. & 190 millions. \\
\hline Main contract & $\begin{array}{l}\text { Working member with a } \\
\text { job on-call contract or a } \\
\text { smart worker contract. }\end{array}$ & $\begin{array}{l}\text { Employee entrepreneur } \\
\text { with a CESA (similar to a } \\
\text { permanent contract). }\end{array}$ & $\begin{array}{l}\text { Fixed-term employment } \\
\text { contracts. }\end{array}$ \\
\hline
\end{tabular}

${ }^{11}$ Deliveroo and Take Eat Easy. 


\section{Prosumers and multi-stakeholder cooperatives}

Digital platforms affect even prosumers and the question we would try to answer is the following: can the model of platform cooperatives, based on the democratization of data and economic resources of the sharing economy in the consumption field, be considered an enabling factor for a fair and inclusive economy generating a positive impact also at the collective, social and environmental level?

To answer this question we will explore the challenges where the cooperative model can develop itself in a better, fair and inclusive economy at local and community level, studying good practices and examples - even of hybrid organizations mixing profit and non-profit models - that testify the strong development of alternative models in which the cooperative form is at the center of a process of value generation (economic, social and environmental) for the community and the territory where it operates.

\section{Italy: participatory, local and self-organized cooperatives around food and sustainability}

Food Coop (http://foodcoop.film/) is a participatory cooperative supermarket born in New York in the United States: members are volunteers who selfmanage the supermarket in an organized and cooperative way, contributing directly and in a distributed way. Members participate (a couple of hours per week) in the typical activities of the operational management of a supermarket. In exchange, they obtain a discount on products, the opportunity to participate in the evaluation, selection, and purchase of products (through dedicated IT systems and technologies), and to the supermarket management (e.g. development of activities and services). During the last years, experiences similar to Food Coop were born in some French cities and in Italy (in Bologna (camilla.coop, since the beginning of 2019), Parma and Cagliari). In the case of Food Coop, the member is not a worker because he has his own work independently and outside the activity of the cooperative.

In a similar way, for agricultural production, collective sharing and direct cultivation, the Arvaia cooperative (www.arvaia.it) was created in Bologna to share cultivation, choices, and purchases of sustainable and organic food products. Arvaia is a multi-stakeholder cooperative, owned by the local community that is composed of both a collective buying group and a group of volunteers. The local community is assisted in the cultivation process by entrepreneurs and professionals of the agricultural field (they also are members). In this platform model citizens - members are engaged as peers in 
the cultivation process and in the decision making process about what kind of cultures to produce and in the end about the decisions concerning the output both for the self-consumption than for the outside market.

Another example in Italy is the community cooperative, which is a multistakeholder company that arises in self-organized forms in small villages at risk of depopulation. In these cases, the platform business model, regardless of technology, proves to be effective both to redistribute resources more equitably and to generate attractiveness to these places (Pais, and Zandonai, 2018).

\section{France: "social impact" urban mobility and PtoP fair markets in cooperative forms}

Rydigo (https://www.ridygo.fr) is the most well-known and in some ways the most significant case of cooperative car sharing on a territorial and personal level. In this enterprise both the technology and the algorithm (created through a machine learning system) have been designed for cooperative management and non-profit organization to redistribute resources to the weaker segments of the labor market. They decided to build their algorithm to redistribute a percentage of the profit to disadvantaged and unemployed people. Their system is based on virtual currency.

Pwiic (https://pwiic.com/) is a cooperative platform born in France and present in other European countries. On Pwiic you can exchange and make available a series of goods and services (small activities) of non-professional nature. The mutual exchange does not generate profit but is destined for the development of the platform and to the payment of the people who work for its development. Pwiic users are not professionals, but people who want to exchange goods and services in a cooperative and non-profit logic base, together with a sense of proximity and distance. Pwiic is a multi-stakeholder cooperative that includes workers (firstly, the founders), prosumers and users.

\section{Spain: Pays Basque: energy democratization and community hub for cooperative citizens}

Colaborabora (www.colaborabora.org) is a network-based business model, where citizens' ideas, skills, and motivations are valorized. Active citizens can participate in finding operational and cooperative solutions to the problems of the neighborhood. Particular attention is given to data-sharing tools to analyze the needs and then plan strategies and projects. In this way, the citizen's data are used to reinforce the belonging and create active citizens' protagonists of 
city life and development. The efforts and the projects of Colaborabora are not just related to physical places of the community and the people living in. They also developed WikiToki (http://wikitoki.org/en) a platform aimed to collect, update and create self-organized PtoP peer-to-peer collaborative projects. Colaborabora Wikitoki Co-Lab is a community hub space situated in the historic quarter of San Francisco Las Cortes in Bilbao. In addition to a small group of social animators, designers and city planners, the protagonists and members of this business project are the citizens themselves who contribute directly through the design, the development of participatory local development projects.

The second example from the Region of Pays Basque is Goiener (www.goiener.com). Goiener is a cooperative company whose mission is to alleviate energy poverty in the Basque Country and Spain, through the diffusion and use of alternative and sustainable energies owned by the local community itself. Members can choose to be active users who participate directly in the promotion, development, and purchase of instruments and power plants for alternative energy production. In this second case, they help to raise awareness and educate the local community about the opportunity and value of this energy and economic transition. Unlike active users, working members in Goiener have specific working times, roles and responsibilities and are regularly classified as workers in function of the budget available and the needs and strategies of the owners.

\section{Discussion}

The following will focus on the effects of the combination of digital platform technology with worker-owned cooperatives and consumer and multistakeholder cooperatives. In the first section, we observe how worker-owned cooperatives across Europe give a new sense to platform work introducing the platform technology in their activity. In the second section, we focus on how introducing cooperation and sharing practices modifies consumers' approach to digital platforms. In both cases, we highlight the main consequences of this combination on the organizational model and the engagement level of individuals. 


\section{Platform work and worker-owned cooperatives}

Despite Doc Servizi, BEC-Coopaname and Smart Belgium did not meet for many years ${ }^{12}$, were born for different reasons ${ }^{13}$, and are three different kinds of worker-owned cooperatives ${ }^{14}$, they all appear to offer decent work conditions and access to social protection scheme to workers and new forms of work that are usually excluded to the employment law. As shown by the Smart Belgium example with food delivery platform workers, this kind of solution may be applied even to platforms' providers and workers, and offering them better working conditions, because it is an enough flexible organization model for at least two reasons. First of all, the employees are not paid in the same way and in function of predetermined brackets (Martinelli, 2018) because the wage of each worker is calculated on the basis of the actual income of his activity, in the same way it varies in platform work. Secondly, workers have the opportunity to keep the freedom in the management of activity (where, when, with whom, etc.), consistent with platform work mechanisms.

Moreover, this model implies even two important effects differentiating a cooperative platform from a classical digital platform, both on the use of technology in function of the organizational model and the engagement of workers. We observe that even if with different timing, specific purposes and results, Doc Servizi, Coopaname and Smart Belgium have chosen technology to improve their organization, services, and activity. Despite this, for no one of these long history cooperatives technology is at the core of the business, as in the case of a classical digital platform, but it is considered as a supporting tool for the economic activity of members (Martinelli, and Chiappa, 2019).

Regarding engagement, while in a classical digital platform workers are completely outsourced and isolated, in cooperatives workers are connected. This is evident if we refer, for example, to the representation activity that both Coopaname and Doc Servizi, and Smart Belgium with riders, have begun to perform as spokespeople for their members.

\footnotetext{
12 While the BEC movement and the Smart ecosystem are connected for more than 10 years, Doc Servizi met Smart Belgium only in 2013 and then Coopaname in 2016.

${ }^{13}$ Doc Servizi (1990) was created to valorise collectively the work of professionals in the field of music, theatre and arts through self-management cooperation, BEC-Coopaname (1994) were created to offer a cooperative alternative to the individual creation of an enterprise, and Smart Belgium (1998) was created to mutualize a digital platform that makes it easier to invoice discontinued activities for artists.

${ }^{14}$ Doc Servizi is a self-management platform cooperative, Coopaname is a Business and employment cooperatives (BEC), and Smart Belgium is a mutual risk cooperative.
} 


\section{Consumer platforms and multi-stakeholder cooperation}

Concerning the consumer and multistakeholder cooperatives that we presented, we will underline some effects of the merger of consumer platforms and multi-stakeholder cooperation focusing on the organizational model, on the individual - both consumers and workers.

At the organizational level, these business models appeared to be based on self-management practices, in particular, sociocracy (Buck, and Edenburg, 2003; Buck, and Villines, 2007; Rau, and Koch-Gonzalez, 2018). They are essentially models of governance and decision making organized by area of competence, with the shape of connected circles based on the principles of consent and self-organization in small and semi-autonomous teams. In some realities (e.g. FoodCoop, Arvaia, and Goiener), people are included in the organizational and governance model according to the principles of sociocracy. Therefore, the core business area is often composed of mixed groups where workers, users, and other categories of stakeholders of the local community, collaborate for their collective general and specific aims. Concretely, it means that collective and personal purposes are integrated into the organizational model erasing the distinction between governance and operational levels: on one hand, roles are decided by circles and every person has the right to be heard; on the other hand, nobody can be forced to do a task. People are organized in circles with both governance and operational roles following the aim of the circle that is self-organized and partially autonomous at the entrepreneurial level with a system of links (double link) based on people selected roles from other circles.

In general, we observe that these platforms appear rather as genuine and nonextractive models of value sharing towards the community. Involving local users in the management and the governance allows the platform to take into account the places and territories where the value itself is produced.

At the individual level, in opposition to classical digital platforms, single consumers tend to organize themselves in a cooperative model in local and physical markets outside of the digital competition. The active participation is a conscious opportunity and nobody is forced to contribute in terms of personal time. So, even if consumers in these models are the real owners and controllers of the business, the value generation and the sharing level in communities, they are not platform workers engaged in gig economy jobs. Considering that digital cooperatives and so-called platform cooperative models clarify and distinguish the role of consumers and make them cooperate with other actors of the cooperative value chain, we can observe that consumers can assume the 
role of "produser"15 (Toffler, 1980; Bruns, 2009; Grinnell, 2009). Whereas users can be involved at different levels, the role of produser may be a way to measure how much actively a user can participate and be committed in cooperative management, and, to make this voluntary participation accountable, the platform may generate different levels of membership.

In conclusion, the merger of consumer platforms and multi-stakeholder cooperation structure overcomes the difficulties that consumers face when they are involved in a classical digital platform. Considering that consumers are owners of the platform, consumers' law and rights are respected, the quality of products is guaranteed, transparency is a value, and the community integration supports practices of innovation.

\section{Conclusion}

To conclude our analysis, we would like to highlight some general effects of the merger of platform technology with cooperation that distinguishes platform cooperation from classical platform companies.

First of all, we observe that in a cooperative wealth is not concentrated in a few hands, but it is redistributed in an equal way. A digital platform such as Uber, Airbnb or Deliveroo are extractive platforms and obtain their wealth by intermediating among consumers and providers through an application. For this reason, every surplus value they produce by improving the technology goes only to the company owners with no effect on consumers and providers. In a cooperative platform model, the digital platform is owned by cooperative members; there is, then, a coincidence between owners and providers/consumers and every improvement and optimization of technology brings new shared wealth with a multiplier effect. The digital platform becomes a cooperative platform because it is the technological tool assuring the sharing of costs and resources, generation and redistribution of wealth, and, above all, disintermediation (Martinelli, and Chiappa, 2019).

For this reason, the digital platform is not the core business of the cooperative, but it is shaped following members' and community's needs. The digital platform becomes an inclusive technology because it enables the participation of each individual. Then, cooperation may find ways to facilitate transparency

\footnotetext{
15 "Produser" is a hybrid term that combines "producer" and "user" to refer to an individual (or a group of individuals) who is engaged in the culture of peer production amid the emergence of new information environment.
} 
(e.g. in the data management), accountability, and relationships and exchanges among members.

Another relevant issue concerns the fact that the cooperative model can represent a concrete laboratory where consumers and workers can be involved in the operational and governance level in a multi-stakeholder organization. For example, while the consumer of a profit company generates an advantage for himself and the profit enterprise (e.g. Airbnb hosts), the consumer partner of a cooperative is called to cooperate with other partners for the improvement and achievement of results of the company with an attention to its belonging community, finding forms of economic recognition in this participation.

This higher level of engagement is linked with the fact that in a cooperative each person - worker as provider or consumer - is directly involved in the company. When a person enters a cooperative he becomes a member of a company based on democratic governance ("One head, One vote") and he participates in the shared ownership buying a quote of the cooperative. Consequently, members are more than employees because they become entrepreneurs participating in business risk.

According to Benkler (2007), there are three dimensions of the "networked information economy", which directly affect the improvement of people's practical skills: 1) improvement of the individual's ability to work in an autonomous way and with others; 2 ) individuals work better with others when there are no price and hierarchy constraints, which were typical of other economic and social model; 3) individuals become more efficient in organizations that operate outside the market sphere. In the context of the digital economy and platform network business models, we observe that cooperation and social economy enterprises may effectively support the improvement of all these skills. In fact, at the organizational level, being engaged as entrepreneurs, members may be more active and experiment with new roles, develop new skills, and have access to leadership experiences. This engagement may also lead to the decision to be involved in projects concerning not only the cooperative but even the community or even the society to which cooperative members belong, to improve the living and working conditions of other inhabitants. Therefore, the cooperation's potentiality to activate both collaboration and self-organization among people, consumers, and workers, seems to be one key factor in the framework of the cooperative platform economy. 


\section{Bibliography}

ALOISI, A. (2016), "Commoditized workers: case study research on labour law issues arising from a set of 'on-demand/gig economy' platforms", Comparative Labor Law and Policy Journal, 37 (3): 653-690.

BAKER, D. (2014), Don't Buy the 'Sharing Economy' Hype: Airbnb and Uber Are Facilitating Ripoffs, The Guardian, 27 May

(http://www.theguardian.com/commentisfree/2014/may/27/airbnb-uber-taxesregulation).

BALLON, J., C. BODET, M.-C. BUREAU, A. CORSANI, N. DE GRENIER, and A.-L. DESGRIS (2018), "La investigación como herramienta de cambio democrático: la experiencia de dos cooperativas de activitades y de empleo", Revista del Centro de Estudios de Sociología del Trabajo, (10): 7-37.

BENKLER, Y. (2006), The Wealth of Networks. How Social Production Transforms Markets and Freedom, Yale: Yale University Press.

BEUC (2018), Ensuring Consumer Protection in the Platform Economy - Position Paper, Bureau Européen des Unions de Consommateurs AISBL.

BOST, E. (2011), Aux entreprenants associés. La coopérative d'activités et d'emploi, Valence: Repas.

BOUDES, M. (2019), Labour transformation and institutional re-arrangement in France, in ROELANTS, B., EUM, H., ESIM, S., NOVKOVIC, S., and KATAJAMAÄKI, W. (eds.), Cooperatives and the world of work, Oxen and New York: Routledge.

BRUNS, A. (2009) "From Prosumer to Produser: Understanding User-Led Content Creation", Conference paper, Transforming Audiences 2009, 3-4 September, London.

BUCK, J., and G. EDENBURG (2003), The creative forces of self-organizing, Rotterdam: Sociocratic Center.

BUCK, J., and S. VILLINES (2007), We the people. Consenting to a deeper democracy. A guide to Sociocratic principles and methods, Sociocracy.info Edition.

BUREAU, M.-C., and A. CORSANI (2015), "Les coopératives d'activités et d'emploi : pratiques d'innovation institutionnelle", Revue française de socio-économie, (15).

CAROLI, S., G. GUERINI and S. BOZZONI (2018), Una cittadinanza digitale per uscire dalle prigioni del web, Vita, 4 May

(http://www.vita.it/it/article/2018/05/04/una-cittadinanza-digitale-per-usciredalle-prigioni-del-web/146736/).

CASTELVETRI, L. (2010), Le fonti del diritto del lavoro, Padova: CEDAM.

Cecop (2019), All for one. Response of worker-owned cooperatives to non standard employment, Brussels.

CHERRY, A.M. and ALOISI, A. (2017), "Dependent Contractors in the Gig Economy: A Comparative Approach", American University Law Review, 66 (3): 635-689. 
CHIAPPA, C. (2018), Proposta per direzione 18 ottobre 2018 - Verbale riunione del 20/09/2018.

CHIAPPA, C. (2014), Sintesi CCNL allegata al contratto.

CHIAPPA, C. and MARTINELLI, F. (2019), "Doc Servizi e la sua rete: un esempio di alleanza tra cooperazione e sindacati nel mondo dello spettacolo, della creatività e della cultura", Quaderni di Rassegna Sindacale, (13) 2: 109-123.

DRAHOKOUPIL, J. and PIASNA, A. (2019), Work in the platform economy: Deliveroo riders in Belgium and the SMart arrangement, Brussels: ETUI.

DRAHOKOUPIL, J. and FABO, B. (2016), The Platform Economy and the Disruption of the Employment Relationship, Brussels: ETUI Research Paper - Policy Brief $5 / 2016$.

EUROPEAN COMMISSION (2017), Exploratory study of consumer issues in online peerto-peer platform markets. Final report, Luxembourg: Publications Office of the European Union.

GRINNELL, C.K. (2009), "From Consumer to Prosumer to Produser: Who Keeps Shifting My Paradigm? (We Do!)", Public Culture, (21) 3: 577-598.

International Cooperative Alliance (1995), Cooperative identity, values \& principles, Manchester Congress (https://www.ica.coop/en/cooperatives/cooperativeidentity).

Internet Health Report (2019), What if Facebook were owned by its users?, 71-73.

KALAMAR, A. (2013), Sharewashing is the New Greenwashing, OpEd News, 13 May (http://www.opednews.com/articles/Sharewashing-is-the-New-Gr-by-AnthonyKalamar-130513-834.html).

MARTINELLI, F. (2018), “Innovative cooperation's model in Europe. A solution to the growing uncertainty in the world of work", Conference paper, ILPC 2018 International Labour Process Conference, 21-23 March, University of Buenos Aires.

MARTINELLI, F. (2017), Autonomie professionnelle, entrepreneuriat et coopération. Le cas des Coopératives d'Activités et d'Emploi en France, PhD Thesis, Università di Bergamo \& Paris VIII Vincennes-St.-Denis, 6 May (https://aisberg.unibg.it/handle/10446/77189\#.WpPjcyOh1p8).

MARTINELLI, F., and C. CHIAPPA (2019), “Doc Servizi, una rete di professionisti su piattaforma cooperativa", Professionalità, 34 (4): 63-68.

NONY, I. and DE GRENIER, N. (2019), Un salariat sans subordination ?, Les Utopiques, 27 June (http://www.lesutopiques.org/un-salariat-sans-subordination/).

PAIS, I., and F. ZANDONAI, (2018), Little Italian villages show the way to a cooperative economy, Shareable!, 8 May.

RAU, T.J., J. KOCH-GONZALEZ (2018), Many voices one song: shared power with sociocracy, Amherst: Sociocracy For All Center. 
SCHNEIDER, N. (2018), Everything for Everyone: The Radical Tradition that Is Shaping the Next Economy, New York: Nation Books.

SCHNEIDER, N. (2014), Owning Is the New Sharing, Shareable!, 21 December (https://www.shareable.net/blog/owning-is-the-new-sharing).

SCHOLZ, T. (2019), “Own This! Applicare il modello cooperativo all'economia digitale", Pandora Rivista, pp. 46-59.

SCHOLZ, T. (2017), Uberworked and Underpaid. How workers are disrupting the digital economy, Cambridge-Malden: Polity Press.

SCHOLZ, T. (2014), Platform Cooperativism vs. the Sharing Economy, Medium.com, 5 December (https://medium.com/@trebors/platform-cooperativism-vs-thesharing-economy-2ea737f1b5ad).

SCHOLZ, T., and N. SCHNEIDER (eds. 2017), Ours to Hack and to Own. The Rise of Platform Cooperativism, a New Vision for the Future of Work and a Fairer Internet, New York-London: OR Books.

SCHOR, J. (2014), Debating the Sharing Economy, Shareable!, December 15 (https://www.shareable.net/early-data-offers-inside-look-at-homestay-market/).

SMORTO, G., and T. BONINI (eds. 2017), Shareable! L'economia della condivisione, Città di Castello: Edizioni di Comunità.

SRNICEK, N. (2017), Platform Capitalism, Cambridge (UK)-Malden MA (USA): Polity Press.

SUNDARARAJAN, A. (2017), The Sharing Economy. The End of Employment and the Rise of Crowd-Based Capitalism, Cambridge MA (USA)-London (UK): The MIT Press.

TOFFLER, A. (1980), The Third Wave, New York: William Morrow.

VANDAELE, K. (2018), Will trade unions survive in the platform economy? Emerging patterns of platform workers' collective voice and representation in Europe, Bruxelles: ETUI.

VANDAELE, K., A. PIASNA and J. DRAHOKOUPIL (2019), 'Algorithm breakers' are not a different 'species': attitudes towards trade unions of Deliveroo riders in Belgium, Bruxelles: ETUI.

VEYER, S. (2011), Coopaname : les entrepreneurs associés, ou comment repenser le travail, Seminar Économie et sens, École de Paris du management.

VEYER, S. (2007), Le méso-entrepreneuriat: nouvelle frontière des CAE ?, Thesis for CNAM-CESTES Diplôme de dirigeant de coopérative d'activités et d'emploi.

WOOD, A.J., M. GRAHAM, V. LEHDONVIRTA, and I. HJORTH (2018), “Good Gig, Bad Gig: Autonomy and Algorithmic Control in the Global Gig Economy", Work Employment and Society, 1 (20).

ZUBOFF, S. (2019), The Age of Surveillance Capitalism: The Fight for a Human Future at the New Frontier of Power, New York: PublicAffairs. 
This yearly series of working papers (WP) aims to publish works resulting from the scientific network of CIRIEC. The WPs are subject to a review process and are published under the responsibility of the President of the International Scientific Council, the president of the scientific Commissions or the working groups coordinators and of the editor of CIRIEC's international scientific journal, the Annals of Public and Cooperative Economics.

These contributions may be published afterwards in a scientific journal or book.

The contents of the working papers do not involve CIRIEC's responsibility but solely the author(s') one.

The submissions are to be sent to CIRIEC (iriec@uliege.be).

Cette collection annuelle de Working Papers (WP) est destinée à accueillir des travaux issus du réseau scientifique du CIRIEC. Les WP font l'objet d'une procédure d'évaluation et sont publiés sous la responsabilité du président du Conseil scientifique international, des présidents des Commissions scientifiques ou des coordinateurs des groupes de travail et du rédacteur de la revue scientifique internationale du CIRIEC, les Annales de l'économie publique, sociale et coopérative.

Ces contributions peuvent faire l'objet d'une publication scientifique ultérieure.

Le contenu des WP n'engage en rien la responsabilité du CIRIEC mais uniquement celle du ou des auteurs.

Les soumissions sont à envoyer au CIRIEC (ciriec@uliege.be).

This working paper is indexed and available in RePEc

Ce working paper est indexé et disponible dans RePEc

ISSN 2070-8289

ISBN 978-2-931051-26-9

EAN 9782931051269

http://doi.org/10.25518/ciriec.wp201927

D/2019/1406/27-d 


\section{WP Collection 2019}

2019/01 Évolutions récentes de l'économie sociale dans l'Union européenne Rafael CHAVES \& José Luis MONZÓN

2019/02 Recent Evolutions of the Social Economy in the European Union Rafael CHAVES \& José Luis MONZÓN

2019/03 Evolución reciente de la economía social en la Unión Europea Rafael CHAVES \& José Luis MONZÓN

2019/04 Die jüngsten Entwicklungen der Sozialwirtschaft in der Europäischen Union Rafael CHAVES \& José Luis MONZÓN

2019/05 Recente ontwikkelingen in de sociale economie in de Europese Unie Rafael CHAVES \& José Luis MONZÓN

2019/06 Italian cooperatives: an analysis of their economic performances, employment characteristics and innovation processes based on combined used of official data Carlo BORZAGA, Manlio CALZARONI, Chiara CARINI, Massimo LORI

2019/07 Rôle de l'Innovation Sociale dans le Développement Socioéconomique au Maroc : Premières Constatations à partir de la Littérature, et Etude de Cas de 4 Associations Socialement Innovantes Abdellatif BOUAZZA \& Youssef NAFIL

2019/08 De l'intérêt de créer un nouveau concept : la lucrativité limitée Laetitia DRIGUEZ

2019/09 International City Network and Public-Private Cooperation for Urban WaterEnvironment Management: A Study of Japanese Public Water Services' Overseas Expansion Naoki FUJIWARA

2019/10 Partnering with Civil Society Organizations. The role of volunteers and not for profit organizations in the provision of welfare services Federica VIGANÒ \& Andrea SALUSTRI

2019/11 ICT and Ethical Finance: Fostering Social Innovation and Financial Inclusion Gian-Luca GASPARINI \& Aurora PROSPERO

2019/12 New Trends in the Social and Solidarity Economy Regarding Agriculture and Food: A Comparison between France and India Antoine PERRIN

2019/13 Workers BuyOut: why employee-owned enterprises are more resilient than corporate business in time of economic and financial crisis? The case of Emilia-Romagna Region Andrea BASSI \& Alessandro FABBRI

2019/14 How Social Enterprises Contribute to Alternative Food Systems Anastasia COSTANTINI, Gianluca PASTORELLI \& Alessia SEBILLO 
2019/15 Measuring the Impact of a Social Enterprise - Case Study CONCORDIA Bakery, Romania Irina-Sinziana OPINCARU \& Doina CRÂNGAȘU

2019/16 Vers un nouveau paradigme ancré dans les pratiques d'économie solidaire : le délibéralisme Éric DACHEUX \& Daniel GOUJON

2019/17 Social enterprises role in Romanian welfare system Mihaela LAMBRU \& Claudia PETRESCU

2019/18 Community financing in the German organic food sector: a key for sustainable food systems?

Gerlinde BEHRENDT, Sarah PETER, Simone STERLY \& Anna Maria HÄRING

2019/19 Self-Management Report in Brazil - Technical Concepts and Challenges Daniel Francisco NAGAO MENEZES

2019/20 Creación de un nuevo bien común para las cooperativas agrícolas: Big data, TIC e intercambio de datos Cynthia GIAGNOCAVO \& Daniel HERNÁNDEZ CÁCERES

2019/21 Job Quality in Economy for the Common Good Firms in Austria and Germany Laia OLLÉ-ESPLUGA, Johanna MUCKENHUBER \& Markus HADLER

2019/22 Social Innovation - Scaling Social Impact: a Danish Case Study Roger SPEAR \& Carman Ka Man CHAN

2019/23 Shared-Services Cooperatives: Strengthening Local Economies through Collaboration Christina CLAMP, Eklou AMENDAH \& Carol COREN

2019/24 Les bonnes pratiques en matière de politiques publiques relatives à l'économie sociale européenne, à la suite de la crise économique Rafael CHAVES \& José Luis MONZÓN

2019/25 Best practices in public policies regarding the European Social Economy post the economic crisis

Rafael CHAVES \& José Luis MONZÓN

2019/26 Buenas prácticas en las políticas públicas relativas a la economía social europea tras la crisis económica

Rafael CHAVES \& José Luis MONZÓN

2019/27 Platform Cooperativism in Italy and in Europe Francesca MARTINELLI, Samuele BOZZONI, Simone CAROLI, Francesca TAMASCELLI \& Giuseppe GUERINI 


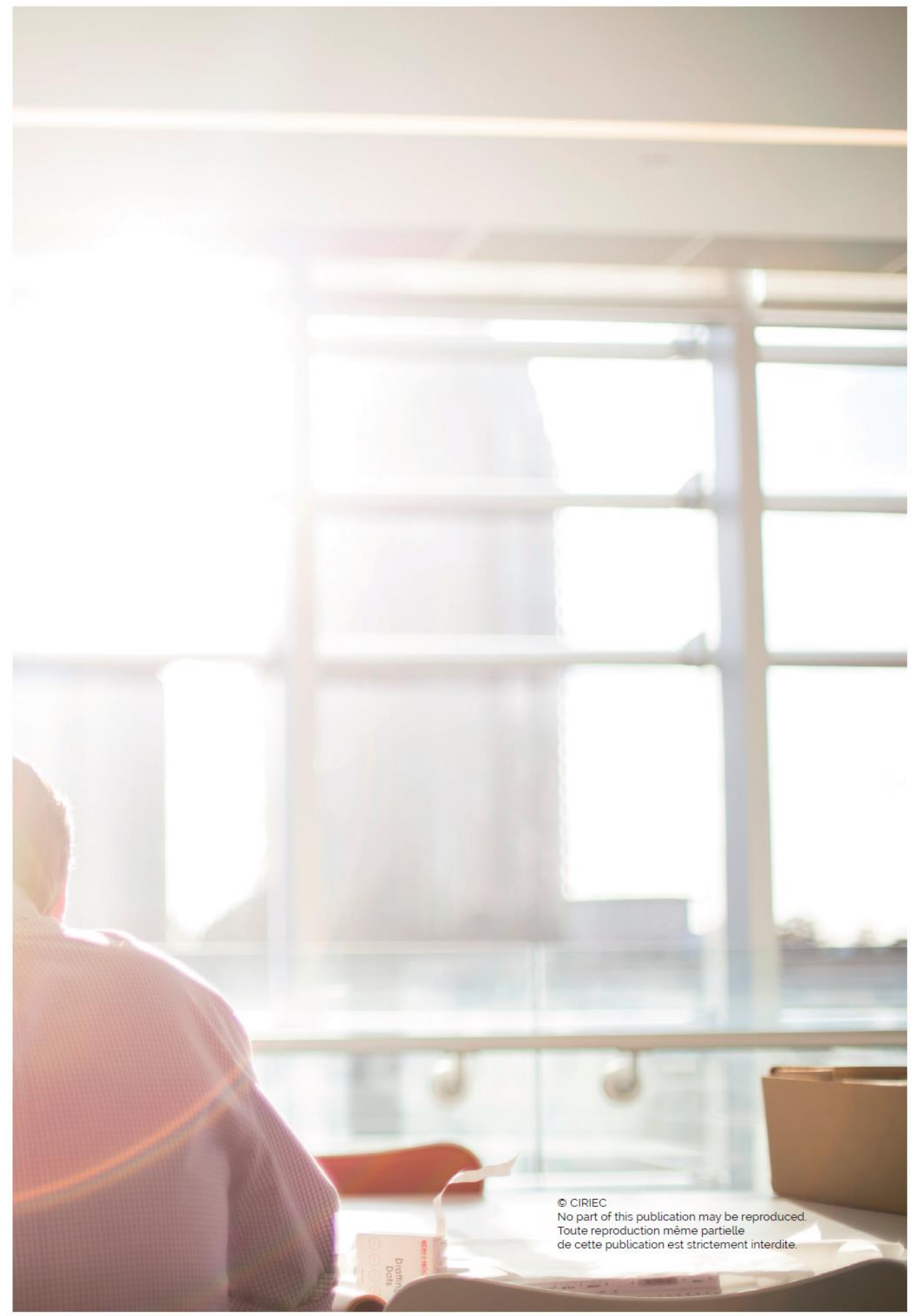


CIRIEC (International Centre of Research and Information on the Public, Social and Cooperative Economy) is a non-governmental international scientific organization.

Its objectives are to undertake and promote the collection of information, scientific research, and the publication of works on economic sectors and activities oriented towards the service of the general and collective interest: action by the State and the local and regional public authorities in economic fields (economic policy, regulation); public utilities; public and mixed enterprises at the national, regional and municipal levels; the so-called "social economy" (not-for-profit economy, cooperatives, mutuals, and non-profit organizations; etc.).

In these fields CIRIEC seeks to offer information and opportunities for mutual enrichment to practitioners and academics and for promoting international action. It develops activities of interest for both managers and researchers.

Le CIRIEC (Centre International de Recherches et d'Information sur l'Economie Publique, Sociale et Coopérative) est une organisation scientifique internationale non gouvernementale.

Ses objectifs sont d'assurer et de promouvoir la collecte d'informations, la recherche scientifique et la publication de travaux concernant les secteurs économiques et les activités orientés vers le service de l'intérêt général et collectif : l'action de l'Etat et des pouvoirs publics régionaux et locaux dans les domaines économiques (politique économique. régulation) : les services publics : les entreprises publiques et mixtes aux niveaux national, régional et local: « l'économie sociale » : coopératives, mutuelles et associations sans but lucratif : etc.

Le CIRIEC a pour but de mettre à la disposition des praticiens et des scientifiques des informations concernant ces différents domaines, de leur fournir des occasions d'enrichissement mutuel et de promouvoir une action et une réflexion internationales. Il développe des activités qui intéressent tant les gestionnaires que les chercheurs scientifiques.

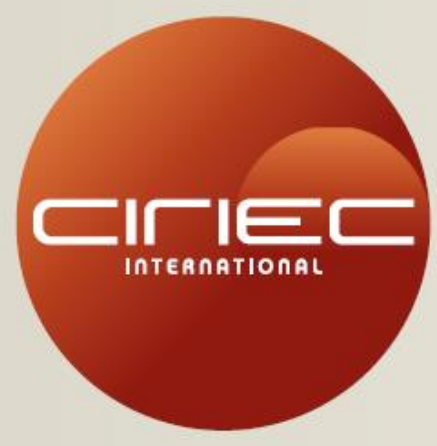

INTERNATIONAL CENTRE OF RESEARCH AND INFORMATION ON THE PUBLIC, SOCIAL AND COOPERATIVE ECONOMY-AISBL

CENTRE INTERNATIONAL DE RECHERCHES ET D'INFORMATION SUR L'ÉCONOMIE PUBLIQUE, SOCIALE ET COOPÉRATIVE - AISBL

Universite de Liège | Quartier Agora | Place des Orateurs 1 | Bātiment B33 boite 6 | BE-4000 Liege (Belgium) | T+32(0)436627 46 | F+32(0)43662958 ciriec@ulg.ac.be | www.cirieculg.ac.be 